\title{
Studying Contingency Systematically
}

\section{Citation}

Einstein, Katherine Levine, and Jennifer Hochschild. 2017. "Studying Contingency

Systematically." In Governing in a Polarized Age: Elections, Parties, and Political Representation in America, eds. Alan S. Gerber and Eric Schickler, 304-327. Cambridge: Cambridge University Press.

\section{Permanent link}

http://nrs.harvard.edu/urn-3:HUL.InstRepos:34390343

\section{Terms of Use}

This article was downloaded from Harvard University's DASH repository, and is made available under the terms and conditions applicable to Open Access Policy Articles, as set forth at http:// nrs.harvard.edu/urn-3:HUL.InstRepos:dash.current.terms-of-use\#OAP

\section{Share Your Story}

The Harvard community has made this article openly available.

Please share how this access benefits you. Submit a story.

Accessibility 


\title{
Studying Contingency Systematically
}

\author{
Katherine Levine Einstein \\ Boston University \\ Jennifer Hochschild \\ Harvard University
}

$12 / 22 / 15$

Prepared for Governing in a Polarized Age: Elections, Parties, and Political

Representation in America, edited by Alan Gerber and Eric Schickler, Cambridge University Press, 2016 forthcoming

DRAFT: please do not quote or cite without permission from one of the authors.

Comments welcome and will be used: kleinst@bu.edu and Hochschild@gov.harvard.edu 
In the realm of primitive building blocks, there is a case for ranking events as the equals of interests and preferences in a seriously explanatory political science.

-- (Mayhew 2005: 486).

Prominent in accounts like these is human agency. . . . To a degree, the history of the relevant processes is a sequence of what these various figures did. It could have evolved otherwise had they done otherwise.

Scholars of political behavior have long debated the circumstances under which individuals change their minds about salient issues, and the circumstances under which such changes matter for political or policy outcomes. The main conclusion of individuallevel studies is that stabilizing forces-group membership and identity, patterns of cognitive processing, interests, habit - usually outweigh the impetus for attitude change. The usual conclusion is similar at the institutional level: at least in the United States, stabilizing forces-the entrenched two-party system, legislative rules and norms, iron triangles and the iron law of oligarchy, racial or class domination - often outlast all but very strong efforts to change policies in response to attitudinal changes.

Alteration does occur, however, in individuals, institutions, and laws, and political scientists usually reach for systematic, theoretically parsimonious explanatory frameworks. High quality political science is often defined, in fact, as a persuasive causal abstraction from the particularities of place, time, person, or policy content. ${ }^{1}$ David Mayhew (2005, 2009), however, has argued that proper nouns, dates, events, and accidents of history are essential raw material for analyzing how and why American politics and political views develop and change. In recent decades he has advocated close attention to contingency understood as human agency or even happenstance; "as a collective explanatory enterprise, the profession may be under-investing in factors that are proximate, short-term, or contingent" (Mayhew 2009: 99). Although by no means simply a claim that "stuff happens," this focus is a far cry from the bold simplifications in his earlier work (as in The Electoral Connection) or the usual explanatory ambitions of political scientists.

We take up Mayhew's call for incorporating contingency into the study of American politics, examining when and how unique events can spur opinion change, and when and how opinion change can eventuate in new laws, rules, or rulers. Using case studies ranging from the 1960 s civil rights movement to the current politics of global warming, we begin to develop a theory of studying contingency systematically

\footnotetext{
${ }^{1}$ In this aspiration or achievement, political scientists differ radically from historians, for whom "contingency is everything," as a colleague of one of us put it in a committee meeting. Thus historically-oriented political science has a very different feel from politically-oriented history.
} 
[building on (Shapiro and Bedi 2009)]. We generate many more loose ends than completed fabrics, and conclude by ruminating on the prospects for rigorous study of how political outcomes "could have evolved otherwise had. . . [various figures] done otherwise."

\section{Clarifying Terms}

For Mayhew, contingent events span everything from the Civil War or World War II (Mayhew 2005) to particular moments such as the "great Mississippi flood of 1927" that led to the Flood Control Act of 1928 (Mayhew 2007: 122). That is, contingency may encompass an extended set of linked actions that develop a distinctive momentum, or may focus more narrowly on a unique and unforeseen occurrence. ${ }^{2}$ A complete systematic study of contingency would incorporate the implications of change on the scale of wars or world-wide epidemics, but we limit our attention in this chapter to specific incidents, actions, or social disturbances. ${ }^{3}$

Along with scope, one must specify the kind of phenomenon that counts as a politically relevant contingency. One elected official responded to a draft of this chapter by urging a focus only on human agency, on the grounds that "events are the conditioning factor but intentions and goals shape the meaning of the event." That is a plausible argument, of course; it underlies constructivist theories in the social sciences and post-structuralism in the humanities. But it is not our argument. We follow Mayhew in broadening the scope of our inquiry to "triggering events" ranging from a flood to a currency crisis, an international dispute, a technological innovation, or a political actor's malfeasance (Mayhew 2009: 122-123). Theoretical refinement might usefully cluster or even filter out some types of incidents; as Robert Lieberman has observed, , "things that could have come out differently but for a chance, singular event play a different role in systematic theorizing about politics from human action undertaken through willful choice" (, comments, May 30, 2013). But the theory is too undeveloped to warrant such refinement at this point.

Finally, a full theory of contingency would need to grapple with the distinction between triggering events that were in some sense predictable and those that were completely novel to the relevant political actors. School shootings such as those of Columbine High School in Colorado or Sandy Hook Elementary School in Connecticut were not in a literal sense predictable or predicted; no one could anticipate that children at those particular locations would be killed. But mass shooting incidents in the United States have occurred often enough over the past few decades that it is entirely foreseeable that another will occur, and plausible that it will occur in a school. In contrast, some triggering events are "circumstances of 'unmeasurable uncertainty'. ... . $[A] n y$ valid basis for classifying instances is absent. Effects and outcomes of action cannot be calculated because such situations are unlike any other. . . 'The situation

\footnotetext{
${ }^{2}$ (Clark 2013) provides a good example of the claim that wars and their impact are radically contingent.

${ }^{3}$ see (Schedler 2009) for a valiant effort to categorize contingencies,.
} 
dealt with is in a high degree unique'" [(Katznelson 2013): 33; internal quotations are from (Knight 1921): 225, 233..] Examples of unmeasurable uncertainty include the creation of Nazi death camps and the detonation of an atomic bomb over a city.

Once again, a full theory of contingency's impact on political attitudes and outcomes would need to distinguish between the anxiety of predictable uncertainty and the "radical. . . fear" (Katznelson 2013: 33) of unmeasurable uncertainty. We limit ourselves in this chapter, however, to the relatively more tractable issue of predictable uncertainty.

\section{Two Contingent Events}

We begin to develop a theory of contingency by exploring two instances in which singular events, directly created or closely followed by human agency, seemed likely to shock the American public and public officials into action. They are the Sandy Hook School massacre and Superstorm Sandy. The elements of these cases -- their basic contours and the public's and elites' immediate responses -- provide the raw material for beginning to study contingency systematically.

Sandy Hook and Gun Control: On December 14, 2012, Adam Lanza used three of his mother's legally bought semi-automatic guns and one combat shotgun to murderher and 20 children and 6 adults at Sandy Hook Elementary School in Newtown, Connecticut. He then killed himself.

Although not the only high profile mass shooting in 2012, the Sandy Hook murders set some grim records. The incident was the second deadliest mass shooting by a single person in American history, behind only the Virginia Tech massacre in 2007; it was the deadliest school shooting in any public school in the United States. The youth and innocence of the children, along with the heroism of their teachers, suggested that even gun-loving Americans might think twice about the United States' gun laws in the wake of the tragedy.

Indeed, publicity was immediate, intense, and worldwide. LexisNexis reported 2445 newspaper articles and 2057 television and radio stories in the week after the shootings. ${ }^{4}$ President Obama's televised speech on the day of the killings reminding watchers that "as a country, we have been through this too many times. Whether it's an elementary school in Newtown, or a shopping mall in Oregon, or a temple in Wisconsin, or a movie theater in Aurora, or a street corner in Chicago--these neighborhoods are our neighborhoods, and these children are our children." He pledged that "we're going to have to come together and take meaningful action to prevent more tragedies like this, regardless of the politics.... And I will do everything in my power as President to help"(Obama 2012). He reiterated that pledge over the next few months, including in speeches in January 2013 and the State of the Union address in February: "I

\footnotetext{
${ }^{4}$ We searched LexisNexis Academic for "Sandy Hook" between December 14 and 22, 2012 in, respectively, "headline and lead" for all newspapers, and "everywhere" in TV and radio transcripts.
} 
know this is not the first time this country has debated how to reduce gun violence. But this time is different."

Prominent media and political elites agreed that Sandy Hook meant that the politics of gun control had changed. Hendrik Hertzberg of The New Yorker, to cite only one example, wrote that "the most obviously sensible solutions ... are universally and, alas, correctly seen as out of reach. ... But lesser steps. . . are, for the first time in nearly a generation, imaginable. There is, for the moment, a perceptible change in the weather" (Hertzberg 2013). Some politicians were less cautious: Republican former member of Congress Joe Scarborough - a recipient of the National Rifle Association's (NRA) highest rating during his four terms-observed that "Friday changed everything. It must change everything. ... Our Bill of Rights does not guarantee gun manufacturers the absolute right to sell military-styled high-caliber semi-automatic combat assault rifles with high capacity magazines to whoever the hell they want." Democratic Senator Joe Manchin-also lauded by the NRA for his vote record-similarly called for a "common sense discussion" in which "everything should be on the table" (Kurtz 2012). Other members of Congress also promised immediate action, the Vice President met with stakeholders in order to draft legislation, states began legislative efforts to control aspects of gun sales - and sales of guns, ammunitions, and magazines rose rapidly in anticipation of coming restrictions.

Most Americans supported this new push for gun control. By December 19, 2012, nine-tenths claimed to have heard or read "a lot" about the shooting. Although large majorities continued to oppose bans on owning handguns throughout the winter of 2013, and the public was split on whether various measures would have prevented the Sandy Hook killings, anywhere from a small majority to 95 percent endorsed proposals to monitor purchases, limit access to ammunition, or otherwise manage gun ownership. In most cases, these are higher proportions than endorsed a similar proposal before December 14, 2012. It is not surprising, therefore, that 52 percent agreed in a January 2013 poll that "this incident has made you more likely to support some forms of gun control" (42 percent said "no difference"). (All evidence in this paragraph is from Pollingreport.com, "Gun Control").

The best available tracking poll question, used by both the Gallup Organization and NBC News/Wall Street Journal, asks respondents if laws covering the sale of firearms should be made "more strict, less strict, or kept as they are now?" These polls are especially valuable because they use the same question wording over time, and the question has been asked repeatedly regardless of whether gun control is in the news. ${ }^{5}$ Although support for stiffer gun laws had been steadily declining, Sandy Hook spurred a

${ }^{5}$ Polling organizations usually ask about gun control only soon after a mass shooting or other highly visible crime; using just these surveys would bias our efforts to assess whether Sandy Hook had a measurable impact on gun control attitudes. The same methodological problem pertains to measuring the impact of many other contingencies, so we focus on events for which there are at least some before-and-after measures of opinion. 
sharp change: while in October 2011, only 43 percent of Americans favored stricter gun laws, on December 19, 2012, that figure was 58 percent. Roughly three fifths of respondents continued to support stricter laws through January $2014 .{ }^{6}$ That differs noticeably from the absence of sustained change in public opinion in response to the Columbine killings in April 1999.

Figure 1. Public support for gun control, 1990-2014

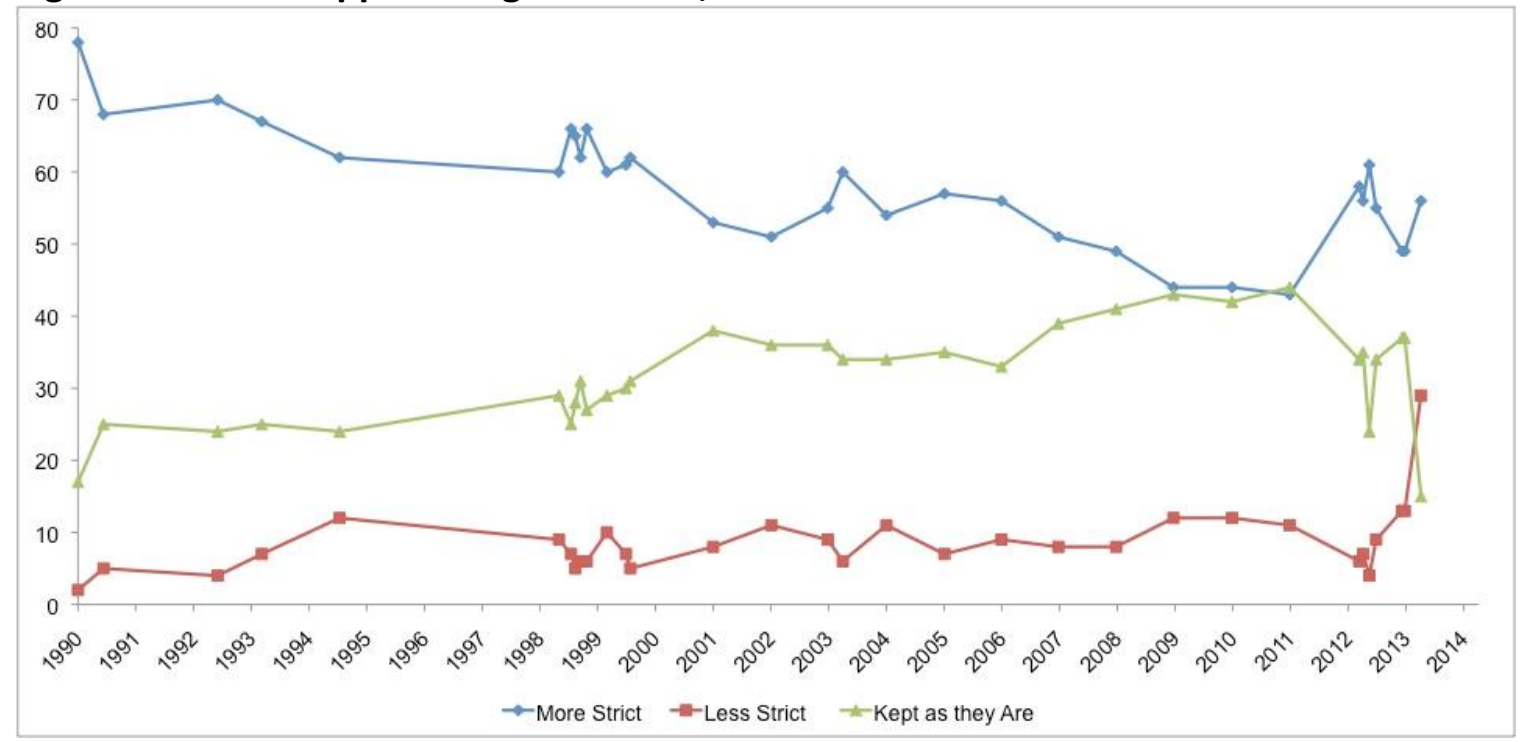

Source: Polls from Gallup Organization and NBC/Wall Street Journal, in (Roper Center for Public Opinion Research 2014). The question reads: "In general, do you feel that the laws covering the sale of firearms should be made more strict, less strict, or kept as they are now?" (with slight variants in wording).

A different method of parsing public views provides further support for the claim that it seemed as though "this time... [was] different." Through LexisNexis, Danny Hayes (Hayes 2013) examined the number of newspaper articles using the phrase "gun control" in the wake of prominent mass shootings in Newtown [Sandy Hook], Virginia Tech, and Aurora, and after the shooting of Representative Gabrielle Giffords. Figure 2 displays a graph reproduced from his data:

\footnotetext{
${ }^{6}$ The proportion of respondents favoring less strict gun control initially decreased in the wake of Sandy Hook, but rose sharply in January 2014, suggesting a polarization of the public. We believe that these intense opponents of gun control are one reason that Sandy Hook spurred policy change only at the state and local level, an issue we explore later in this chapter.
} 
Figure 2. News stories mentioning "gun control"

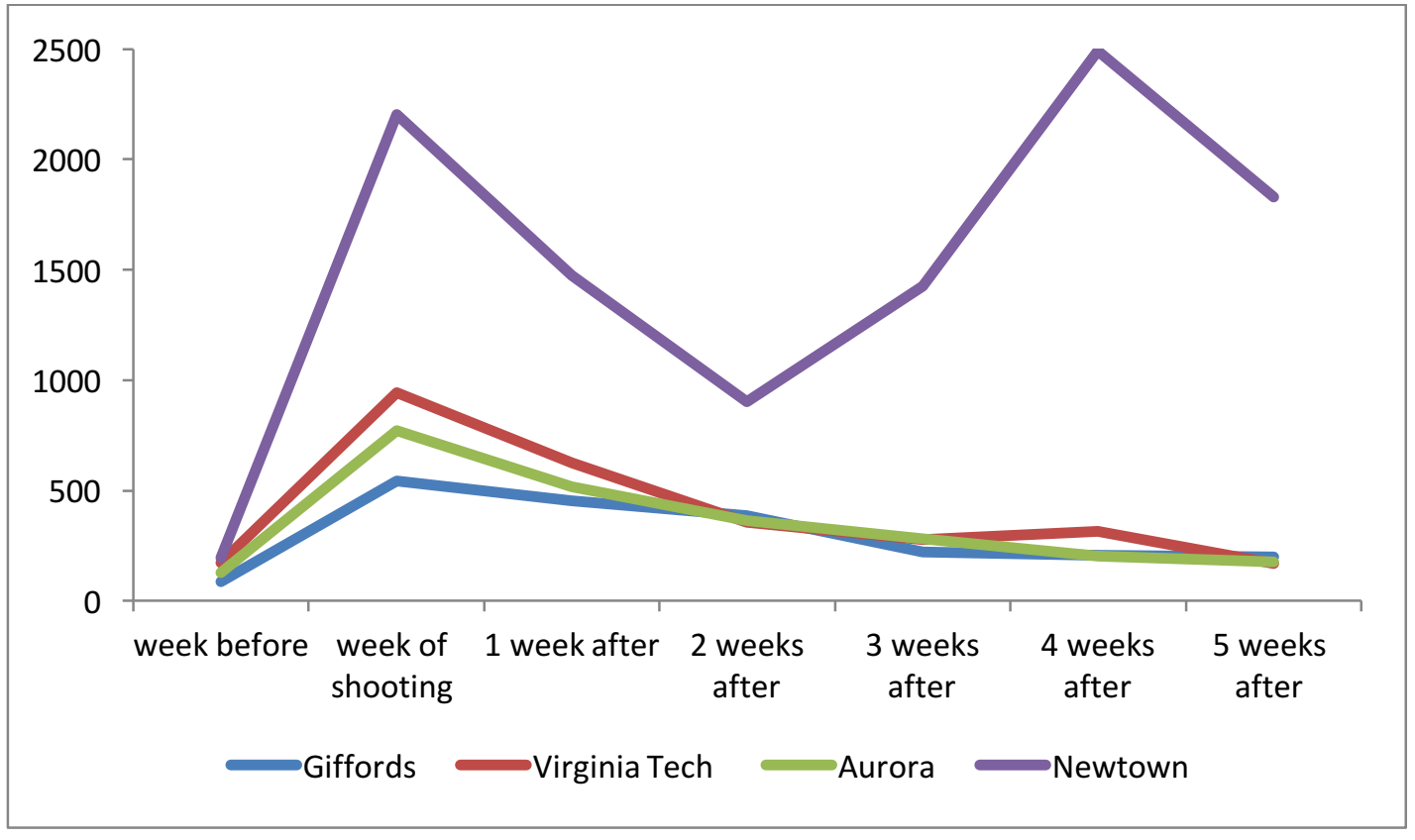

Media interest in the wake of Sandy Hook was markedly different than in other mass shootings, with mentions of gun control lasting far beyond what they had in earlier incidents. The sustained change in public opinion, the continued media attention, and the powerful response from public officials of both parties all suggest that the murders at Sandy Hook School are the type of seminal event that Mayhew urges us to analyze.

Superstorm Sandy and Global Warming: In late October 2012, a massive hurricane and a winter storm merged over the Atlantic Ocean, forming what the media quickly dubbed a "superstorm." This enormous storm came only a year after Hurricane Irene devastated large swaths of New England. Irene's destruction, however, occurred mainly in sparsely populated areas of Vermont; in contrast, Superstorm Sandy made landfall in media- and population-rich New Jersey, wreaking havoc on low-lying areas across the New York City metropolitan corridor. It caused 72 direct deaths and 87 indirect deaths, rendering it the deadliest hurricane to strike the United States since Hurricane Katrina in 2005. It also cost the United States at least $\$ 71$ billion dollars (in current 2012 dollars) in property damage. In constant 2010 dollars, it was the second costliest US hurricane since 1900 [(National Hurricane Center 2011); (National Hurricane Center 2013)].

The combination of Sandy's and Irene's damage, coming soon after other "weird weather" events including wildfires and droughts, spurred climate scientists to hope that Americans had reached a turning point in their views on climate change policy. Recalling Cleveland's flammable river, Michael Mann put it most succinctly: "This may 
be that sort of Cuyahoga River moment for climate change" (Boxall and Banerjee 2012). A researcher on environmental psychology outlines why such a public opinion shift would be both plausible and expected: "polar bear images and melting glaciers do raise people's concern, but they feel disempowered because they cannot do anything about it, whereas the local thing they understand" (Gray 2011). More formally, reminders of remote threats raise concern about global warming but not motivation to act, whereas personal experience with floods renders individuals more likely to agree that climate change is occurring and more likely to change their lifestyles to conserve energy (Spence, Poortinga et al. 2011). ${ }^{7}$

Nonetheless, Hurricane Sandy had little visible impact on public opinion. One careful researcher found no statistically significant difference in belief in global warming and preferences about climate change policy between respondents interviewed immediately before and after the storm (Environmental and Energy Study Institute 2013). We similarly found no difference in commitment to climate change policy before and after the storm, as shown in Figure $3:^{8}$

Figure 3. Commitment to climate change policy before and after Superstorm Sandy

\footnotetext{
${ }^{7}$ Note that Superstorm Sandy need not have been causally related to climate change for it to serve as a focusing event that affects public or elite opinion.

${ }^{8}$ We examined all polls on global warming policy in Roper Center's iPoll database from June 1, 2012 to May 1, 2013. When available, we used items that directly asked whether climate change should be a top policy priority for the United States. When policy questions were not available, we used a broader question asking if global warming was a serious issue. .

The surveys are: Pew Research Center (June 13, 2012; November 9, 2012; January 10, 2013); Gallup Organization (August 31, 2012; January 9, 2013); ABC News, Washington Post (October 4, 2012); Associated Press, GfK (November 28, 2012); Quinnipiac University (November 29, 2012); Yale University (March 7, 2013); Washington Post, Stanford University (March 13, 2013).
} 


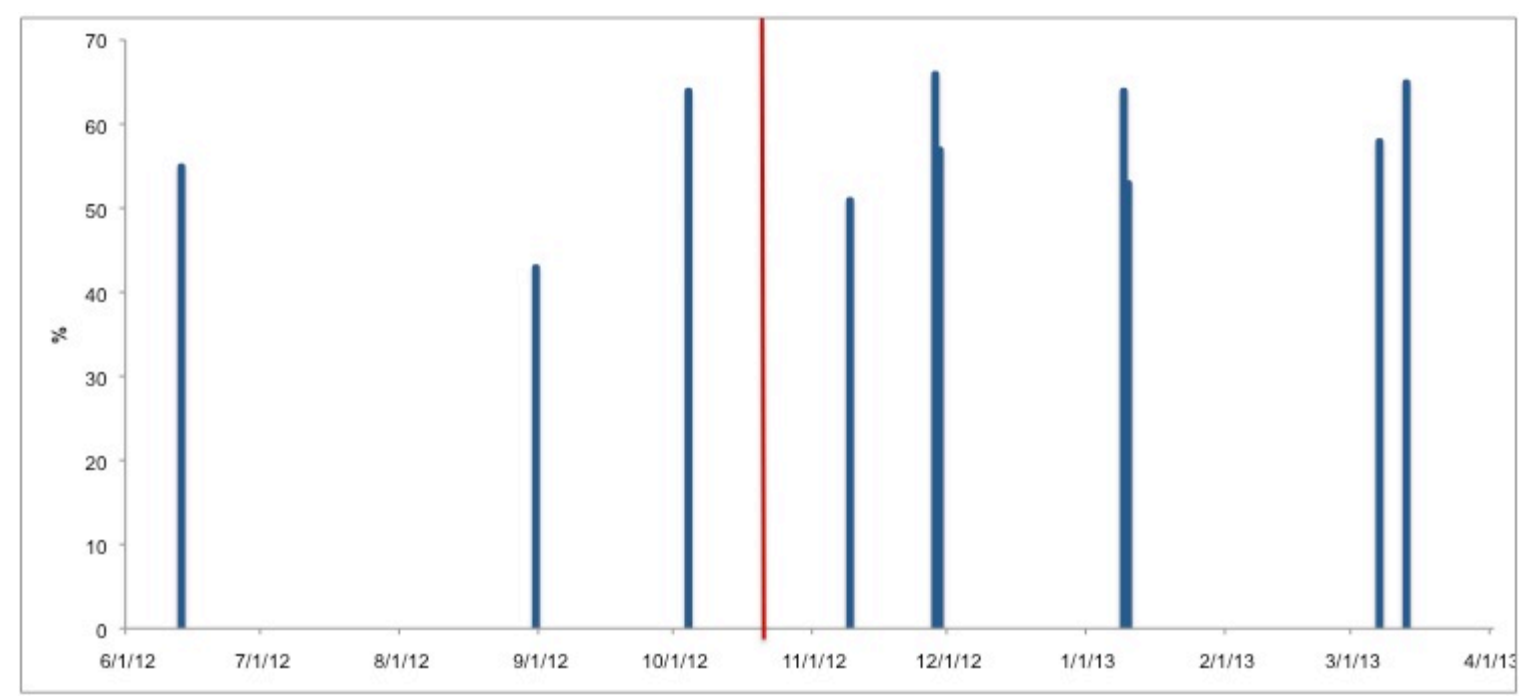

Source: see note 8.

Across eleven months and ten relevant survey items, an average of 58 percent of Americans endorsed greater governmental attention to climate change; these results do not differ markedly before and after Sandy's landfall on October 29, 2012.

In contrast to its minimal impact on public opinion, Hurricane Sandy elicited strong responses from important elite actors of both major political parties. New York Governor Andrew Cuomo immediately linked the storm to climate change and the need for policies to tackle it: "Part of learning from [Hurricane Sandy] is the recognition that climate change is a reality, extreme weather is a reality, it is a reality that we are vulnerable. ... Protecting this state from coastal flooding is a massive, massive undertaking. But it's a conversation I think is overdue"(Vielkind 2012). Connecticut's governor Dan Malloy made the same attribution to the storm (along with other blockbuster storms): "Climate change is giving more severe weather more frequently as the environment continues to warm" (Bass 2013). New York Mayor Michael Bloomberg overrode his Republican affiliation to endorse Barack Obama for the presidency on the basis of Obama's record on climate change: "Our climate is changing. And, while the increase in extreme weather we have experienced in New York City and around the world may or may not be the result of it, the risk that it might be-given this week's devastation - should compel all elected leaders to take immediate action" (Bloomberg 2012). The president of ConservAmerica, a "right-leaning environmental group," sought to move environmental politics back into the Nixon-era realm of nonpartisanship: "'With a majority of Americans already expressing concern about climate change and most others trying to make sense of destructive and unprecedented weather, voters of all political stripes will be looking for leaders willing to tackle the problem and offer real solutions. There is no political future in the climate denial game, and I hope my fellow Republicans can now see the political pitfalls of being bullied by 
the most radical and irresponsible voices in our party'" [Rob Sisson, quoted in (Sheppard 2013)].

Sandy Hook and Sandy, then, have an important commonality: both events provoked an immediate and sharp elite response. In the former case, political actors who had opposed gun control displayed a public about-face; in the latter case, a prominent politician endorsed a candidate of the opposite party. The public's response to these two events, in contrast, differed markedly. Sandy Hook spurred a considerable rise in support for gun control, while Americans' opinions about environmental policy remained unchanged in the face of Hurricane Sandy. How might these differences in response to an unpredicted and shocking event matter for policy change? To answer that question, we turn to a more systematic exploration of responses to contingent events.

\section{Responses to Contingent Events}

The core elements of our nascent theory of the politics of contingency form a decision tree. Moving down particular branches expands, reduces, or eliminates the chance that an unpredicted event or human action will shape public opinion or policy choices. Figure 4 displays the decision tree, with accompanying numbers to match the text below. Row 1 presents a dichotomy between a politically-relevant response and no politicallyrelevant response. This is the stage of analysis demonstrated in our exploration of Sandy Hook and Hurricane Sandy: both led to a substantial public and/or elite response that seemed to imply policy action. Row 2 explores whether (and if so, why) elites or the public sustain their response. Row 3 concludes by investigating whether elite or public responsiveness, or lack thereof, is associated with policy change at the national or local levels, and why such change occurs, if it does. We continue to use Sandy Hook and Sandy to illustrate the branches, but, when appropriate, we present evidence from other cases ranging from Pearl Harbor to urban riots.

Figure 4. Contingent event decision tree 


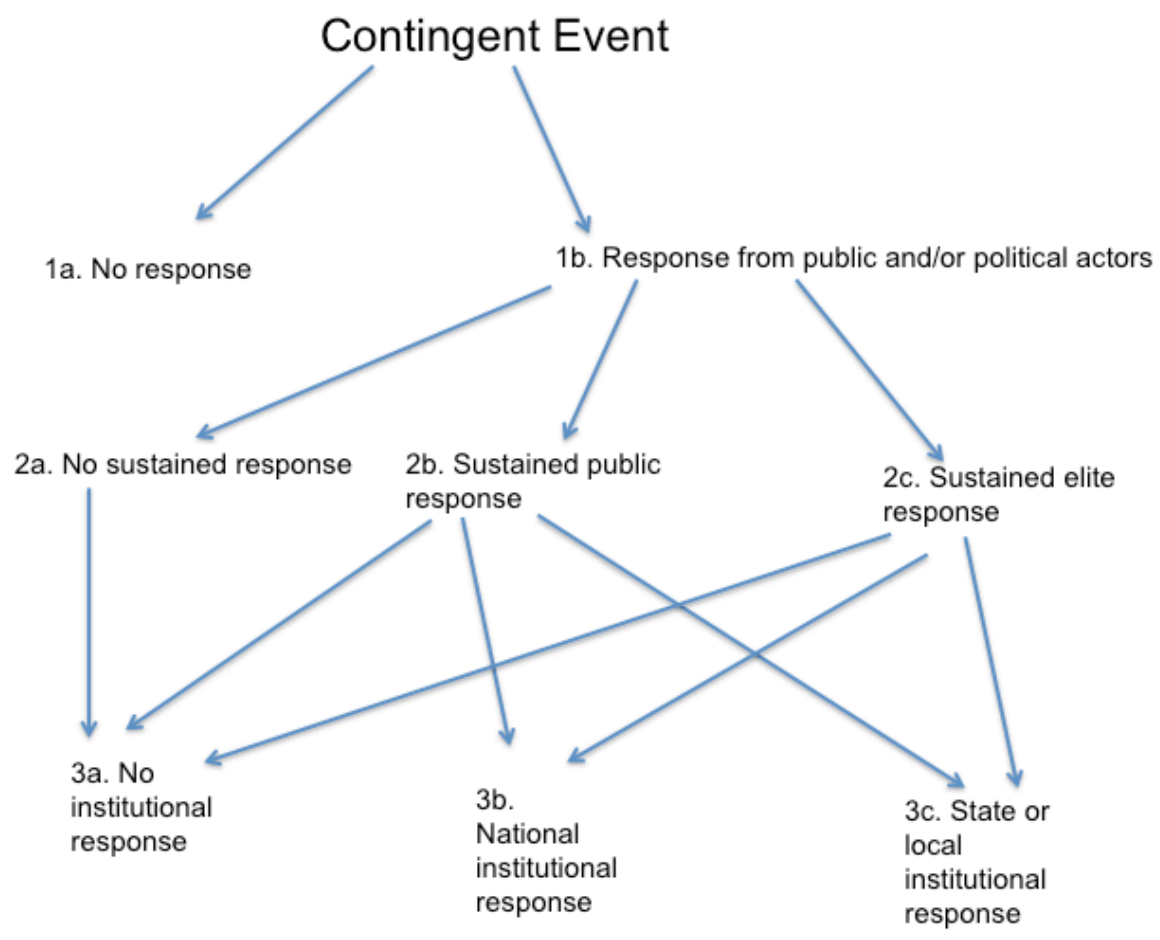

1a. No or minimal politically-relevant response from the media, public, or political actors: If a potentially significant event or action does not evoke a response from one or more politically relevant sectors of society, it will not in fact become a significant event. A complete theory of how to study contingency systematically would need to explain this non-event; as most other scholars are likely to do, however, we simply note it here and turn our attention to more potent events.

1b. Response from the public, media, or political actors: This is the threshold condition for an unpredicted event or human action to become politically relevant. Both Hurricane Sandy and the Sandy Hook killings fall into this category: Sandy Hook spurred media attention as well as elite and public responses, while Sandyreceived media attention and moved the opinions of relevant and important elites.

2a. No sustained politically-relevant response: In a world crowded with events and actions, only a few capture the attention of citizens, the media, or elites. Moreover, only a fraction of these attention-attracting events spur sustained attention with political implications. History is littered with celebrity deaths, sensational court trials, and tragic plane crashes that evoked a flurry of media, elite, and public attention before soon receding from view. While some of these potentially salient events turn out to be too trivial or confusing to attract politically meaningful and sustained attention, others require deeper explanations to distinguish events that generate brief spikes in attention 
from those with more staying power. The rest of line 2 in the decision tree provides the opportunity to explore that issue.

2b. Sustaining public attention: A great deal of research, of course, examines the growth and maintenance of the public's attention to phenomena identified as actual or potential public issues or problems. To that large literature, we add two additional mechanisms that seem especially important for retaining public engagement with a contingent event or action.

2b1. Citizens available to be galvanized: The first mechanism is the proportion of the public available to be affected. Many or even most Americans are unlikely to change their views in response to an event or action. They may be deeply committed to their current standpoint and unwilling to change it (Green, Palmquist et al. 2004); motivated reasoning may lead them to incorporate a new phenomenon into extant perspectives (Lodge and Taber 2013); or they may simply be unaware of the event or action. But some can and will respond to an incident that they deem significant; how many is the crucial question here.

The people most likely to be mobilized in response to a contingent incident are those who know relevant factual information, perhaps understand its political import, but up to now have failed to use it when forging policy judgments or taking political action. They can be contrasted with those whose presumed knowledge, views, and commitments must all be changed in order for them to know and use appropriate facts in making political choices, or those who have no knowledge, views, or even awareness of the subject. Albeit for different reasons, people in both of the latter categories are unlikely to respond to new information or an unpredicted event or action [for a more extensive analysis, see (Hochschild and Einstein 2015)

Thus, we expect unpredicted events to have more noticeable and lasting effects when more Americans are available to be galvanized; a comparison of views related to Sandy Hook and Hurricane Sandy demonstrates this mechanism in action. Consider Figure 1. While about two-thirds of survey respondents had held clear views on gun control in the decade before 2012-10 percent favoring less strict regulations and 40 to 60 percent endorsing stricter policies-one-third consistently fell into the question's middle category of "keep firearms policies as they are." The children's murders changed the views of many in this moderate, or perhaps uncertain, group. The proportion of Americans endorsing less strict policies changed only slightly in the shooting's aftermath-decreasing by 2 to 7 percentage points in polls through April 2013-while the proportion endorsing stricter laws rose by 10 to 20 percentage points over the same months. Almost all of the "stricter" responses came at the expense of the "do not change" responses. In short, a third to half of the one-third of Americans who had previously expressed no strong view about firearms control moved into the ranks of those supporting stronger limits in the months after, and presumably in direct response to, Sandy Hook.

Contrast this movement with views on climate change policies. We classify an individual who knows that global warming is happening, damaging, and man-made, but 
who does not support government action to address climate change, as available to be galvanized by an event such as Hurricane Sandy. We lack as consistent a series of survey items as were available on gun control, but luckily the Gallup Organization had asked a set of relevant questions in March 2012, seven months before the hurricane. We operationalized correct information as agreement both that global warming is happening and that it is substantially caused by human action. Only a third of respondents were correctly informed by this measure, and only a quarter of that group, on average, did not already endorse the eight policy proposals on offer in the survey. Thus only 8 percent of the full sample were available to be persuaded of the need for policy efforts around climate change in response to a relevant event. There were simply not enough Americans lacking strong views about global warming for even a contingent event as powerful as a massive hurricane to affect the public's policy views very much

2b2. Repetition: Ample research in political science and psychology shows that persuasive effects generally decay over time, with the impact of one-off events usually being short-lived and ineffectual [(Chong and Druckman 2010); (Kuklinski et al. 2000); (Berinsky 2013)]. With rare exceptions, an event must be reinforced by further, similar events from which one can draw the same policy lessons in order to have an long-term consequence. $^{9}$

The American public's and political officials' responses to racially inflected violent protests in the summer of 1967 and April 1968 demonstrate the impact of reinforcement by further, similar, events. Although violent protest - sometimes severe and extensive -- had occurred in American cities for several years before then, the number and intensity spiked between July 1967 and July 1968. Figure 5 shows the pattern of protest-related arrests from 1964 through 1972, along with the proportion of Americans who identified "social control" as the most important problem facing the country.

${ }^{9}$ One apparent exception, which seems to prove the general rule, is Americans' response to Japan's attacks on Pearl Harbor on December 7, 1941. Starting in March 1937, for the next four years no more than 30 percent of the public (often as low as 5 percent) agreed that the United States should enter the burgeoning European and then Asian war. Majorities often opposed even selling supplies or ships. Support for war increased only slightly over this period. A week after the Pearl Harbor attack, however, 97 percent and 91 percent respectively approved Congressional declarations of war against Japan and Germany (Gallup, December 12-17, 1941). By January 1942, almost a fifth were concerned that the United States was not "doing all it can toward winning the war" (Gallup, January 1942. All data are from Roper Center iPoll.)

We label this exception "apparent" in response to Adam Berinsky's claim (Berinsky 2009) that the American public was already fairly interventionist before the attack; if correct, his argument undermines the particular example but not our theoretical claim. 
Figure 5:

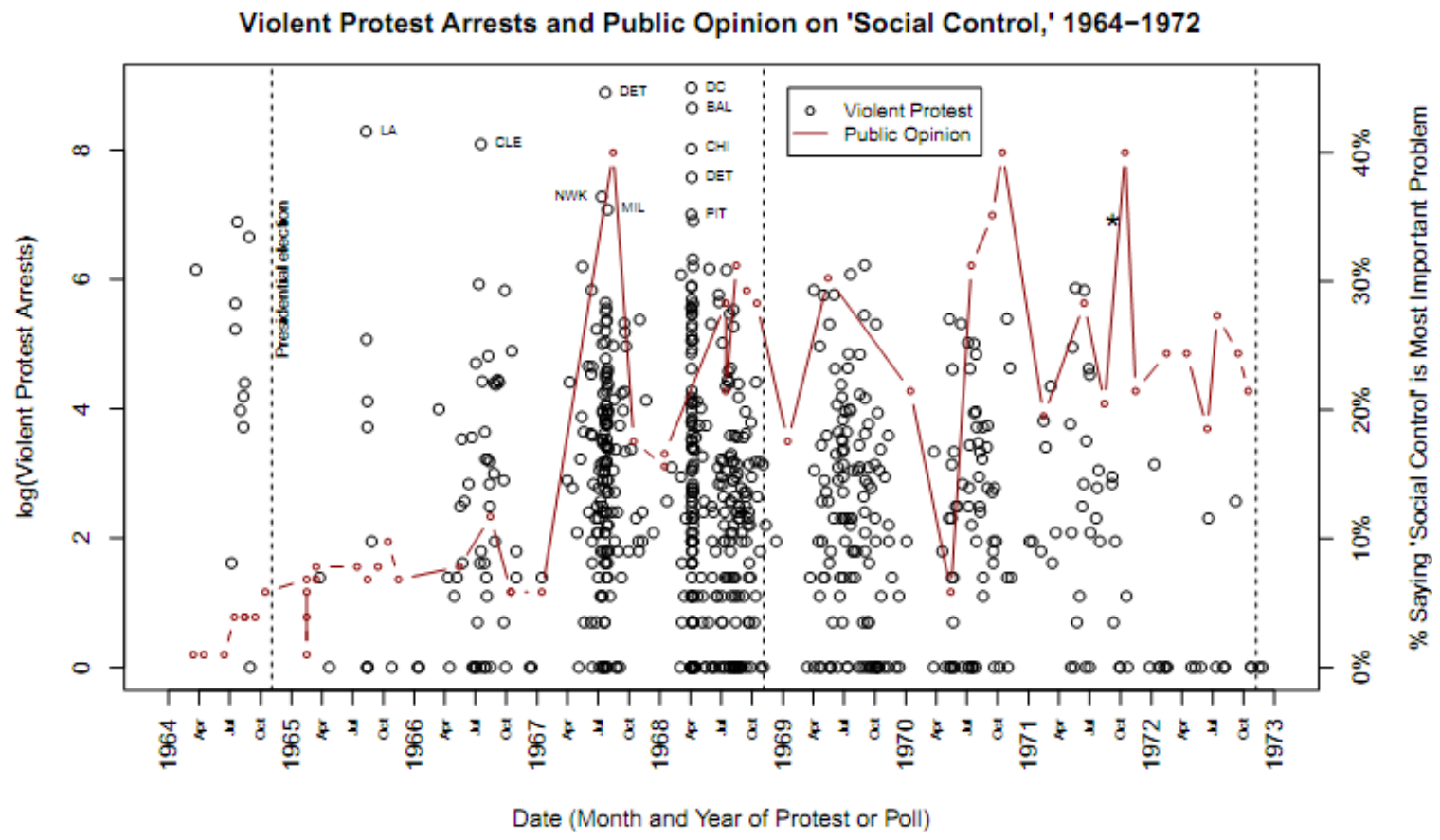

Source: Wasow 2015.

The public's focus on social control rose and fell, seasonally, during the 1960s; this was, after all, the era of the Vietnam war, student unrest, and rising inflation so people had many other political issues to think about. But public attention was clearly greater after July 1967 than before and, with the exception of one anomalous survey, it remained high for half a decade even as the number of violent protests tailed off somewhat. Policy and electoral responses were extensive, deep, and long-lasting.

2c: Sustaining elite attention: An issue need not have persistent or even strong shortterm public support in order to generate a meaningful policy response. Many laws are passed, taxes raised or lowered, or regulations promulgated without knowledge from more than a few key actors [(Howard 1999); (Mettler 2011); (Brixi, Valenduc et al. 2004)]. So the decision tree's row 2 includes a third branch, focusing on elite actors.

The set of relevant actors includes elected officials as well as issue advocates, policy entrepreneurs, lobbying and interest groups, regulators, and so on. As with public opinion, large and sophisticated scholarly literatures have grown up around all of these actors and their behavior in setting agendas, framing problems and solutions, mobilizing supporters, and attaining policy goals. To this literature we add three elements that seem especially useful for explaining when elites give sustained attention to contingent events or actions. 
2c1: Shock or outrage: Public actors are people as well as politicians, so their emotions can affect or even determine their political actions. Some contingent events are so powerful that they evoke a felt need to respond. The reactions of politicians like Joe Manchin, previously an opponent of gun control, to the horrors of the Sandy Hook massacre fall into this category. Similarly, senators or representatives whose children develop rare or serious diseases sometimes sponsor legislation to provide research funds or compensatory regulations for the condition. The 1965 voting rights demonstrations in Selma, Alabama provide another famous instance. A week after the Bloody Sunday beatings of marchers and two days after even more people braved the dangers of the Edmund Pettus Bridge, President Johnson presented a bill to a joint session of Congress that eventually became the Voting Rights Act. His speech became iconic:

What happened in Selma is part of a far larger movement which reaches into every section and state of America. . . . Their cause must be our cause, too, because it is not just Negroes but really it is all of us who must overcome the crippling legacy of bigotry and injustice. And we shall overcome.

2c2: Personal political advantage or issue promotion: Although occasionally idealists, public actors are more often politicians, adept at turning an unpredicted and attentiongrabbing event to their personal political advantage - or, more charitably, to the benefit of a cherished policy position. New York Mayor Michael Bloomberg had advocated a more aggressive governmental response to climate change long before Hurricane Sandy flooded his downtown. In 2011, for example, he argued in the United Nations that cities must lead the battle against global warming: "As mayors - the great pragmatists of the world's stage and directly responsible for the well-being of the majority of the world's people-we don't have the luxury of simply talking about change but not delivering it" (News Watch 2012). His plea for national and even international attention to climate change in the wake of Hurricane Sandy was thus more an instance of issue promotion than a conversion experience; in our terminology, the contingent path of the storm gave the mayor an opportunity to reinforce and demonstrate his sustained attention to a long-standing concern.

2c3: Partisan advantage: A further step away from acting out of moral outrage is the strategy of using a contingent event or action to promote one political party at the expense of other(s). A striking instance is that of "birthers," as they are known to their opponents. The Republican Party has parlayed three contingent facts--the Democratic president lived in Indonesia for a time as a child, his father was African, and his name has an uncanny resemblance to that of a hated and feared enemy-into a powerful device for stoking opposition to his presidency and policies.

Before September 11, 2001, most Americans had no opinions about Muslims or were mildly favorable. Views of Muslims showed no partisan divide. After September 11,2001 , hostility rose, especially though not uniquely among Republicans (see Roper Center for Public Opinion Research, and Hochschild et al. 2012: 153-155). Given that set of views, tying anti-Muslim sentiment to Barack Hussein Obama has proven irresistible. 
No responsible politician espouses hostility to Muslims or Islam, but some suggest or hint not only that Obama is a Muslim but also that such an affiliation makes one's patriotism or American identity suspect. In 2010, for example, former Alaska governor Sarah Palin "accidentally" promoted a tweet showing a sign that read, "The blood of Jesus against Obama History made 4 Nov 2008 a Taliban Muslim illegally elected President USA: Hussein." In the same year, while criticizing Obama administration policies, Palin noted that "I'm not calling anyone un-American, but the unintended consequences of these actions, the results, are un-American." Speaker of the House John Boehner was similarly coy when asked about some Americans' belief that Obama is a Muslim: "It really is not our job to tell the American people what to believe and what to think."

By 2010, up to a quarter of Americans agreed that Obama is a Muslim and another 25 to 40 percent, depending on the poll, did not venture an opinion on his religion. $A$ third of conservative Republicans agreed. Those who perceived Obama to be a Muslim were less likely to vote for him than those who did not [(Layman, Kalkan et al. 2009); (Smith n.d. c. 2010)]. The causal connections among Americans' views of Islam, Republican elites' hints that Obama is an un-American Muslim, the public's beliefs about Obama's religion, and vote choice are complex. Probably causation runs in many directions at once and, in any case, explanation of links between elite position-taking and public opinion is not our central concern here. ${ }^{10}$ Our point is more particular: effective politicians are adept at seizing on contingent events or actions in order to put them to partisan use. It may not always work, but it is always tempting.

3a: No or minimal institutional response: Attention to an unpredicted human action or event matters in the public arena only if it affects people's political activity or is associated with institutional or policy responses to the contingency. Line 3 of the decision tree, therefore, addresses whether sustained attention is linked to political or policy change. To begin with the negative case, the belief that Obama is a Muslim has had no traceable policy impact; those who see Obama as un-American would not have voted for him or supported his policy initiatives no matter how many baptisms he underwent. As with the other two nodes in the decision tree identified as "no response," it would be worthwhile to explicate this variety of non-event. But we pass by it here, instead focusing primarily on why the positive cases differ from this cell.

3b: National institutional responses: Sometimes an unexpected event or action does eventuate in a policy response; Mayhew's list of such impactful contingencies ranges from depressions and recessions to wars, assassinations, floods, and groups of unruly citizens. Reams of scholarship are devoted to the issue of how a potential agenda item moves onto the actionable Congressional agenda, and how a bill becomes a law; here

${ }^{10}$ For plausible explanations, see (Nyhan 2010); (Hartman and Newmark 2012); (Langer 2010). The underlying theory in most of these analyses is in (Zaller 1992). 
we offer only two additional considerations that seem especially germane to the study of contingency.

3b1. Fending off further contingency: Some national institutional responses are aimed at minimizing the impact of past contingencies or the likelihood of future unexpected events or actions. The Troubled Asset Relief Program sought to mitigate the almostunanticipated 2008 economic calamity by compensating some individuals and institutions for the disastrous and unintended results of human actions. At the same time, the Federal Reserve Bank's newly invigorated "stress tests" for major banks sought to protect the United States against another crash resulting from contingent combinations of human activities. Analogous governmental protective measures respond to natural disasters, whose occurrence can be expected but whose location cannot be predicted. An example is the National Flood Insurance Act of 1968, intended to buffer home owners from the cost of damage such as that caused by Hurricane Betsy in 1965. This type of government response to an event or action, or to public or elite attention to an event or action, is the most straightforward route down the decision tree of studying contingency systematically.

3b2: An easy fix: National institutional responses to contingent events may also occur because politicians perceive an easy fix to a situation that annoys key voters. A trivial but telling example occurred in 2013. On Monday, April 22, the Federal Aviation Administration furloughed about 10 percent of its air traffic controllers in response to budget limitations caused by the sequestration law. For a few days, flights in five of the United States' largest airports experienced considerable delays. By Friday, both houses of Congress had passed and the president had signed a law permitting the FAA to shift money within its budget categories; the furloughs, and delays, ended before business travelers had to confront a weekend spent in an airport waiting for postponed flights home. In the right conditions, participants in the unwieldy American system of checks and balances can move with alacrity, particularly when traceability is a boon [(Arnold 1990); see also (Huber 2009) and (Wood 2009)].

\section{3c: State or local institutional response}

Sometimes the federal government's failure to act is not merely one of many nonevents, but is itself an occurrence that requires explanation. Sandy Hook provides one such example. Despite a galvanizing event coming after a series of many similar events, up to 95 percent public support for some policy responses, intense media focus, carefully vetted policy proposals, bipartisan sponsorship, and officials' heartfelt pledges of legislation, the Democratically-controlled Senate failed to pass even a token gun control bill in a vote four months after the school murders.

Why? The explanation, in brief, is that Mayhew I ("the electoral connection") (Mayhew 1974) can halt Mayhew II ("events as causes") in its tracks. That is, even the set of characteristics just described may be no match for senators' electoral imperatives.

For one thing, despite the changes in public attitudes about gun control laws reported earlier, the usual partisan divide remained. By February 2013, seven in ten 
Republicans chose "protect[ing] the right of Americans to own guns," while seven in ten Democrats chose "control[ling] gun ownership" in a forced choice item about the more important goal. [Independents split evenly. (Pew Research Center for the People \& the Press 2013)]. Given Republican senators' own ideologies and the nature of their constituencies, their opposition even to a rather anodyne bill to expand background checks could be predicted. But the bill failed in the Senate for an additional reason-four Democrats also voted against it (in addition to the Senate majority leader who voted "no" for procedural reasons). Here too, Mayhew I provides the explanation for this more surprising result: all four were from relatively conservative states. Thus Heidi Heitkamp of North Dakota told critics, "I always had a reputation as somebody who will listen, somebody who is pretty independent-minded but also believes that at the end of the day, you got to listen to your constituents. ... The [telephone] calls literally were before the last day at least 7 to 1 against that bill. ... . This is part of our culture in North Dakota. And they expressed those opinions to me pretty loud and clear" (Raju 2013). ${ }^{11}$ Her three Democratic colleagues said pretty much the same thing.

Where the public, media, or elites show sustained attention to a contingent event or action but the national government does not act, the old trope of states as laboratories of democracy becomes newly salient. The United States has thousands of elected governments; federal inaction may foster action in at least some states and localities. For example:

The more President Obama talks about the need to raise the federal minimum wage, the less likely it appears that Republicans in Congress are inclined to do it.

But the stalemate matters less and less. In the last 14 months, since Mr. Obama first called for the wage increase in his 2013 State of the Union address, seven states and the District of Columbia have raised their own minimum wages, and 34 states have begun legislative debates on the matter. Activists in an additional eight states are pursuing ballot referendums this year to demand an increase in wages for their lowest-paid workers (Shear 2014).

Other issues show the same pattern; in the face of federal inaction on immigration reform, for example, states and cities are acting either to encourage immigration and help the undocumented, or to discourage immigration and punish undocumented status [(Varsanyi 2010); (Ramakrishnan and Lewis 2005); (Community Services Administration n.d.)].

Our two central cases reveal more fully both how states and localities generate institutional responses to contingent events, and how the responses themselves add another layer of contingency. Consider Hurricane Sandy. Despite elites' calls for action, national political actors made virtually no effort to legislate climate change policies, perhaps because of Republican veto power. Local governments, however, particularly those directly affected by Sandy, stepped into the vacuum quickly and aggressively. The plan for "A Stronger, More Resilient New York" included 257 recommendations to strengthen parts of the city most vulnerable to "climate events"; it proposed such things

${ }^{11}$ Mayhew I also explains why even a majority Democratic vote was insufficient; the Senate's filibuster rules dictated the need for a supermajority. 
as adding over 1.2 million cubic yards of sand to city beaches and increasing the height of dunes to alleviate the impact of waves and storm surge (City of New York 2013). As Deputy Mayor for Operations Cas Holloway put it: "The risks from extreme weather and climate change are real, and the City has responded with an ambitious and achievable plan-- a multi-layered strategy of strengthening coastal defenses, upgrading buildings, protecting critical infrastructure, and making neighborhoods safer and more vibrant." Connecticut's state government implemented resilience policies through the Connecticut Climate Preparedness Plan (Department of Energy and Environmental Protection 2013). Boston's Mayor Thomas Menino announced Climate Ready Boston, with a parallel observation: "While the City of Boston had been preparing for the impacts of climate change since 2007, Hurricane Sandy was a gut check. We needed to do more" (Climate Preparedness Task Force 2013).

More broadly, local governments appear to be the most fertile venue for climate policy. As of 2015, 1060 mayors from all fifty states, representing almost 90 million people, have endorsed the U. S. Conference of Mayors Climate Protection Agreement. The Agreement commits participating cities to develop policies to meet or beat the Kyoto Protocol targets, to push state governments to implement similar policies, and to urge Congress to pass greenhouse gas reduction legislation. It would clearly be more efficient and pervasive if the federal government took action, but federal stalemate need not preclude response from other levels of government.

Gun control advocates similarly found some state and local governments more amenable to regulation than was their national counterpart after the Sandy Hook shootings. The Brady Campaign to Prevent Gun Violence reports that, within a year, twenty-one states had passed stricter gun control laws, with eight states' changes classified as "major" (Law Center to Prevent Gun Violence and Brady Campaign to Prevent Gun Violence 2013).

Despite the fact that both inspired local responses to contingency, however, Sandy differs from Sandy Hook in one crucial way. We know of no local government that sought to make its community more vulnerable to the effects of global warming, whereas some states moved in the opposite direction from those lauded by the Brady Campaign's gun control initiative. That is, some states reacted to the Sandy Hook killings by loosening gun control laws. Supporters of looser gun laws refer to the Sandy Hook killings just as do supporters of stricter laws, but to very different ends: "The president is using the massacre at Newtown 'to further his liberal agenda to try and disarm and disenfranchise law-abiding Americans from their enshrined Second Amendment rights" [(Walshe 2013), quoting Alaska House Speaker Mike Chenault].

In short, localities' responses to contingent events or actions may themselves be contingent. Idiosyncratic phenomena--the proximity of an arresting event (Wasow 2014), the ideological or partisan group currently in local power, a policy entrepreneur or crusading newspaper, a skilled interest or advocacy group that can deliver votes (such as the NRA in the case of gun control), or resource-rich foundations or business leaders-- may have a large impact on which local governments act, and what policy outcomes they produce [(Stone, Henig et al. 2001); (Mansbridge 1986) (Shipan and Volden 2008) (Glick and Friedland 2014)]. It is no surprise that states and cities nearest 
to Hurricane Sandy's landfall with liberal governors or mayors responded most strongly, or that Republican-run states and cities rejected gun control most vehemently after Sandy Hook.

Structural characteristics -- population size and distribution, electoral design, community wealth, racial and ethnic composition, cultural and religious formations, region, physical features, transportation patterns, or general patterns of partisanshipadd a further layer of contingency to the question of how local governments respond to contingent events. We expect that the smaller the unit of governance, the more important idiosyncratic actors and actions are relative to deeper and more stable institutional factors in shaping the policy response to contingent events - but that too is a subject for further exploration.

State and local policy responses to unpredicted or unpredictable events or actions are limited; as Edward Glaeser observes, "most localities are very restricted in the kinds of stuff they can do" (Lowrey 2014). But sometimes many piecemeal, partial, multi-directional policy responses have considerable impact, especially in the context of federal government inaction.

\section{Conclusion}

Just as Monsieur Jourdain of Le Bourgeois Gentilhomme was surprised to discover that he had been speaking prose all his life, political scientists might be startled to learn that they have been analyzing contingency throughout their careers. Although M. Jourdain was pleased by the thought ("How grateful am I to you for teaching me that!"), scholars in a discipline that aspires to causal precision may not be so gratified. Nonetheless, as our comments about the large literatures in public opinion, elite incentives, or obstacles to policy change imply, the systematic study of contingency engages widely with political science scholarship. Indeed, studying contingency may simply be the flip side of studying rules, patterns of thought, or institutional design.

The central question in studying contingency systematically is whether the previous sentence is correct. That is, is the study of contingency essentially the same thing as the study of causation, with the focus of attention merely shifted to the unexplained variance that remains after theoretically-based causal analyses have done their work? In that case, captured in shorthand here as Mayhew I, the goal of studying contingency systematically is to reduce its role in both social science explanations and real world politics and policy-making.

Or is politically relevant contingency something distinct and best studied on its own terms, as implied by Mayhew's later assertion of " a case for ranking events as the equals of interests and preferences in a seriously explanatory political science"? In that case, the goal of studying contingency systematically is to develop its explanatory impact in a more robust way than has heretofore been done, and perhaps even to celebrate its place in politics and policy-making.

This chapter has explored the implications of the second choice; we share the view of Mayhew II, that unpredicted or unpredictable events or actions need to be analyzed in ways that move beyond reducing what is left over after developing the implications of the electoral connection or some other general law. But we have been 
constantly reminded that, just as rules operate within unpredictable circumstances, so the impact of unpredicted events develops within a rule-constrained public realm.

Even if the viewpoint of Mayhew II is persuasive, this chapter has just begun the necessary analysis. Basic questions remain, such as which of the phenomena on which we focus are necessary, sufficient, or neither for a contingent event to change views in a sustained way and affect political and policy outcomes. How does one even define and study contingency (Shapiro and Bedi 2009)? What is the role of powerful individual actors in creating exogenous shocks or taking advantage of those that occur during their period in office (Read and Shapiro 2014)? What creates and sustains momentum in public opinion, media attention, elite concern, or partisan jockeying for advantage ${ }^{12}$ Why are state and local responses to an event so varied and seemingly random at times? How might a combination of contingent events yield a political outcome that none would have produced by itself? (Hochschild and Burch 2009).

Our goal has been to open those questions by outlining a framework of when, how, and why idiosyncratic events drive durable and important changes in public opinion and policy. As political scientists, we reject some historians' view that significant change is, by definition, contingent--that a policy's unfolding results arising out of particularities of context and human agency may be retrospectively explained but not prospectively predicted. Along with Mayhew I, we assume that individual and institutional incentives and logics can be identified and used to systematically explain some outcomes. But Mayhew II haunts Mayhew I, and sorting out their relationship seems a goal worth pursuing.

\section{References}

Arnold, R. Douglas (1990). The Logic of Congressional Action. New Haven CT: Yale University Press.

Bass, Paul (2013) "Malloy: "This Is Climate Change"." New Haven Independent, http://www.newhavenindependent.org/index.php/archives/entry/this_is_cl imate_change/

Berinsky, Adam (2009). In Time of War: Understanding American Public Opinion from World War II to Iraq. Chicago IL: University of Chicago Press.

Bloomberg, Michael (2012). "A Vote for a President to Lead on Climate Change." Bloomberg.com, http://www.bloomberg.com/news/2012-11-01/a-vote-fora-president-to-lead-on-climate-change.html Accessed on January 20, 2013.

Boxall, Bettina and Neela Banerjee (2012). "Sandy a Galvanizing Moment for Climate Change." Los Angeles Times. November 4,

Brixi, Hana, et al., eds. (2004). Tax Expenditures--Shedding Light on Government Spending through the Tax System: Lessons from Developed and Transition

12 This question links the study of contingency to the analysis of positive and negative feedback loops. See among others, (Campbell 2003); (Patashnik 2008); (Hochschild 2013). 
Economies. Washington D.C.: International Bank for Reconstruction and Development.

Campbell, Andrea (2003). How Policies Make Citizens: Senior Political Activism and the American Welfare State. Princeton NJ: Princeton University Press.

Chong, Dennis and James Druckman (2010). "Dynamic Public Opinion:

Communication Effects over Time." American Political Science Review 104(4): 663-680.

City of New York (2013). "Mayor Bloomberg Details Progress on Resiliency Projects Outlined in the City's Long-Term Plan to Protect City against the Effects of Climate Change on Hurricane Sandy Anniversary." http://www1.nyc.gov/office-of-the-mayor/news/348-13/mayorbloomberg-details-progress-resiliency-projects-outlined-the-city-s-longterm-plan-to/\#/0

Clark, Christopher (2013). The Sleepwalkers: How Europe Went to War in 1914 New York: Harper.

Climate Preparedness Task Force (2013) "Climate Ready Boston: Municipal Vulnerability to Climate Change." http://www.cityofboston.gov/news/uploads/30044_50_29_58.pdf

Community Services Administration (n.d.). "New Haven's Elm City Resident Card: My City. My Card." http://www.cityofnewhaven.com/csa/newhavenresidents/

Department of Energy and Environmental Protection (2013). "Connecticut Climate Preparedness Plan." http://www.ct.gov/deep/cwp/view.asp?a=4423\&Q=528012\&deepNav_GID= 2121

Environmental and Energy Study Institute (2013). "Public Perceptions About Global Warming and Government Involvement in the Issue." http://www.eesi.org/032813polls

Gray, Louise (2011). "Flooding at Home, Not Polar Bears, Convinces People of ManMade Climate Change." The Telegraph. March 21,

Green, Donald, et al. (2004). Partisan Hearts and Minds. New Haven CT: Yale University Press.

Hartman, Todd and Adam Newmark (2012). "Motivated Reasoning, Political Sophistication, and Associations between President Obama and Islam." PS: Political Science and Politics (July ): 449-455.

Hayes, Danny (2013). "Why This Gun Control Debate Has Been Different." Wonkblog, http://www.washingtonpost.com/blogs/wonkblog/wp/2013/01/28/whythis-gun-control-debate-has-been-different/

Hertzberg, Hendrik (2013)."Shots." The New Yorker. January 7, 17-18.

Hochschild, Jennifer (2013). Dynamics of International Migration: Will Demography Change Politics before Politics Impedes Demographic Change? Cambridge MA, Harvard University, Department of Government.

Hochschild, Jennifer and Traci Burch (2009). "Contingent Public Policies and Racial Hierarchy: Lessons from Immigration and Census Policies. " in Political Contingency: Studying the Unexpected, the Accidental, and the Unforeseen, 
eds. Ian Shapiro and Sonu Bedi. New York: New York University Press: 138170.

Hochschild, Jennifer and Katherine Levine Einstein (2015). Do Facts Matter? Information and Misinformation in American Politics Norman OK: University of Oklahoma Press.

Howard, Christopher (1999). The Hidden Welfare State: Tax Expenditures and Social Policy in the United States. Princeton NJ: Princeton University Press.

Huber, Gregory (2009). "Contingency, Politics, and the Nature of Inquiry: Why NonEvents Matter." in Political Contingency: Studying the Unexpected, the Accidental, and the Unforeseen. eds. Ian Shapiro and Sonu Bedi. New York: New York University Press: 205-221.

Katznelson, Ira (2013). Fear Itself: The New Deal and the Origins of Our Time. New York: Liveright Publishing Co.

Knight, Frank (1921). Risk, Uncertainty, and Profit. Boston: Houghton Mifflin.

Kurtz, Howard (2012). "Some Pro-Gun Voices Now Changing Their View." The Daily Beast, http://www.thedailybeast.com/articles/2012/12/17/some-pro-gunvoices-now-changing-their-view.html

Langer, Gary (2010). "This I Believe." ABC News Online, http://blogs.abcnews.com/thenumbers/2010/08/this-i-believe.html

Law Center to Prevent Gun Violence and Brady Campaign to Prevent Gun Violence (2013). "2013 State Scorecard: Why Gun Laws Matter,"

http://www.bradycampaign.org/sites/default/files/2013-scorecard.pdf

Layman, Geoffrey, et al. (2009). A Muslim President? Assessing the Causes and Consequences of Misperceptions About Barack Obama's Faith in the 2008

Presidential Election. Toronto, Ontario, annual meeting of the American Political Science Association.

Lodge, Milton and Charles Taber (2013). The Rationalizing Voter. New York:

Cambridge University Press.

Lowrey, Annie (2014). "Cities Advance Their Fight against Rising Inequality." New York Times. April 6.

Mansbridge, Jane (1986). Why We Lost the ERA. Chicago: University of Chicago Press.

Mayhew, David (1974). Congress: The Electoral Connection. New Haven CT: Yale University Press.

--- (2010). "Legislative Obstruction." Perspectives on Politics 8(4): 1145-1154.

Mettler, Suzanne (2011). The Submerged State: How Invisible Government Policies Undermine American Democracy. Chicago IL: University of Chicago Press.

National Hurricane Center (2011). "The Deadliest, Costliest, and Most Intense United States Tropical Cyclones from 1851 to 2010 (and Other Frequently Requested Hurricane Facts)."

--- (2013). "Hurricane Sandy: October 22 - 29, 2012 (Tropical Cyclone Report)."

News Watch (2012). "C40 Chair, New York City Mayor Michael R. Bloomberg: 'Cities Are Forging Ahead'."

http://newswatch.nationalgeographic.com/2012/03/14/c40-chair-newyork-city-mayor-michael-r-bloomberg-cities-are-forging-ahead/ 
Nyhan, Brendan (2010). "Pundits Blame the Victims on Obama Muslim Myth." http://www.brendan-nyhan.com/blog/2010/08/pundits-blame-the-victimson-obama-muslim-myth-.html

Obama, Barack (2012). "Statement by the President on the School Shooting in Newtown, Ct." http://www.whitehouse.gov/photos-andvideo/video/2012/12/14/president-obama-makes-statement-shootingnewtown-connecticut\#

Patashnik, Eric (2008). Reforms at Risk: What Happens after Major Policy Changes Are Enacted. Princeton NJ: Princeton University Press.

Pew Research Center for the People \& the Press (2013) "If No Deal Is Struck, Fourin-Ten Say Let the Sequester Happen." http://www.peoplepress.org/2013/02/21/section-1-opinions-about-major-issues/

Raju, Manu (2013). "Heidi Heitkamp Defends Gun Vote." Politico http://www.politico.com/story/2013/04/heidi-heitkamp-defends-gun-vote90600.html

Ramakrishnan, S. Karthick and Paul Lewis (2005). Immigrants and Local Governance: The View from City Hall. San Francisco CA: Public Policy Institute of California.

Read, James and Ian Shapiro (2014). "Transforming Power Relationships: Leadership, Risk, and Hope." American Political Science Review 18(1): 40-53.

Roper Center for Public Opinion Research (2014) "Ipoll." http://www.ropercenter.uconn.edu/

Schedler, Adreas (2009). "Mapping Contingency." in Political Contingency: Studying the Unexpected, the Accidental, and the Unforeseen, eds. Ian Shapiro and Sonu Bedi. New York: New York University Press: 54-78.

Shapiro, Ian and Sonu Bedi, Eds. (2009). Political Contingency: Studying the Unexpected, the Accidental, and the Unforeseen. New York: New York University Press.

Shear, Michael (2014). "After Push by Obama, Minimum-Wage Action Is Moving to the States." New York Times. April 2,

Sheppard, Kate (2013). "Could Chris Christie Bring the Gop around on Climate?" Mother Jones-- Environment, http://www.motherjones.com/environment/2013/02/chris-christieclimate-change

Smith, David Thomas (n.d., c. 2010). The First Muslim President? Causes and Consequences of the Belief that Barack Obama Is a Muslim. Ann Arbor MI, University of Michigan, Department of Political Science.

Spence, A, et al. (2011). "Perceptions of Climate Change and Willingness to Save Energy Related to Flood Experience." Nature Climate Change 1(1): 46-49.

Stone, Clarence, et al. (2001). Building Civic Capacity: The Politics of Reforming Urban Schools. Lawrence KS: University Press of Kansas.

Varsanyi, Monica Ed. (2010). Taking Local Control: Immigration Policy Activism in U.S. Cities and States. Stanford CA: Stanford University Press.

Vielkind, Jimmy (2012). "Cuomo: 'Climate Change Is a Reality...We Are Vulnerable'." Capitol Confidential, 
http://blog.timesunion.com/capitol/archives/162798/cuomo-climatechange-is-a-reality-we-are-vulnerable/

Walshe, Shushannah (2013). "Some States Propose Gun Control Law, Others Say No to Federal Proposals." ABC News. January 19,

Wasow, Omar (2015). "Do Protest Tactics Matter? Effects of the 1960s Black Insurgency on White Attitudes and Voting Behavior." Paper presented at the Center for the Study of Democratic Politics, Princeton University, Princeton NJ, April 9.

Wood, Elisabeth (2009). "Modeling Contingency." in Political Contingency: Studying the Unexpected, the Accidental, and the Unforeseen. eds. Ian Shapiro and Sonu Bedi. New York: New York University Press: 222- 245.

Zaller, John (1992). The Nature and Origins of Mass Opinion. New York: Cambridge University Press. 